\title{
The Pentrich Rebellion - A Nottingham Affair?
}

\section{Richard A. Gaunt}

Department of History, University of Nottingham, Nottingham, UK

Department of History, School of Humanities, University Park, Nottingham, NG7 2RD

richard.gaunt@nottingham.ac.uk

Richard A. Gaunt is Associate Professor in Modern British History at the University of Nottingham. 


\section{The Pentrich Rebellion - A Nottingham Affair?}

This article re-considers Nottingham's role in the events immediately preceding the Pentrich Rebellion of 9-10 June 1817, as well as its reaction on the night of the Rebellion and during its aftermath. It does so in light of two continuing areas of historiographical debate: Nottingham's status as a radical, potentially revolutionary, town, and the Rebellion's links to Luddism. Nottingham loomed large in the planning and course of the Rebellion; it was heavily influenced by the work of a secret committee centred on Nottingham, the North Midlands Committee, which provided essential points of contact with the villages at the heart of the Rebellion. It was also a Rebellion led by a Nottingham man, Jeremiah Brandreth, 'the Nottingham Captain'. However, the effective role played by Nottingham Corporation, in treading the fine line between revolution and reaction, the inability of the radicals to persuade would-be rebels that they had an effective plan, and the ability of the local magistrates and the Home Office to gather intelligence about the Rebellion, all worked against it. The chances of a successful reception in Nottingham were always much lower than the Rebels anticipated.

Keywords: Nottingham: Jeremiah Brandreth: Luddism: Duke of Newcastle: Oliver the Spy

Late in the evening of Monday 9 June 1817, some 50-60 men set out from the villages of Pentrich and South Wingfield in Derbyshire on a fourteen-mile march towards Nottingham. They believed themselves to be in the vanguard of a Rebellion which would see 'clouds of men' descend from the north of England. Huddersfield, Sheffield, Wakefield and Leeds were scheduled to rise the night before, Nottingham, Leicester and Derby the same night and Birmingham the following day. ${ }^{1}$ This self-styled 'army of regenerators', anything upwards of 100,000 strong, would assemble in Nottingham, which was to be made the regional centre of government, well-placed for securing

\footnotetext{
${ }^{1}$ The only other significant activity was 'The Folly Hall Rising' near Huddersfield in the early hours of 9 June 1817: A. J. Brooke, 'The Folly Hall Uprising 1817', Old West Riding: A Collection of Original Articles, 4 (1984), 18-22; also see note 64 below.
} 
communications with the north. From there, they would make their way up the River Trent to Newark. After seizing the arms depot and revenue in the Town Hall, they would sweep south to London and establish a government which would secure their political rights and address their social and economic concerns. Property would be nationalised, the national debt and taxes extinguished and new money issued which everyone would be forced to accept. Britain would become a republic under a new red, white and green tricolour flag. George III would be offered the Presidency of this new Republic but the rebels were unclear about what would happen if this offer was refused. This was the Pentrich Rebellion, whose latter-day fame is largely owing to the attention given to it by E. P. Thompson during the 1960s and whose bicentenary was commemorated in $2017 .^{2}$

The Pentrich rebels were friends, neighbours and relatives living in their local community. The overwhelming majority were connected by ties of family and kinship. They were drawn from the artisan class of framework knitters, quarrymen, iron-workers, stonemasons, and miners. ${ }^{3}$ They were rebels who carried pikes fashioned from ash-poles, topped by hatchets made from old files and chisels; there were pitch forks and iron spikes aplenty but some men carried pistols and firelocks. ${ }^{4}$ They were led by members of their own community - men like William Turner, a 46-year old mason and former soldier, and Isaac Ludlam senior, a 52-year old stone-getter and sometime Methodist

${ }^{2}$ E. P. Thompson, The Making of the English Working Class (Harmondsworth: Penguin Books, 1980 edition), pp. 711-34. The standard history is J. Stevens, England's Last Revolution (Hartington: Moorland Publishing, 1977).

${ }^{3}$ The National Archives [TNA], TS/11/351: of 35 rebels arraigned for trial, there were 13 frameworkknitters, 7 labourers, 5 colliers, 2 stone cutters and representatives of six other artisan trades.

${ }^{4}$ See R. A. Gaunt, 'The Pentrich Rebels (act.1817)', Oxford Dictionary of National Biography [ODNB] (forthcoming, 2018). Details concerning those involved can be gleaned most easily from the transcripts of their trials: W. B. Gurney, The Transcripts of the Trials of Jeremiah Brandreth, William Turner, Isaac Ludlam the Elder, and George Weightman, 2 volumes (London: Butterworth and Son, 1817). 
preacher. ${ }^{5}$ However, they were commanded by a relative stranger in their midst. Jeremiah Brandreth, universally known to the rebels as 'Nottingham' or 'the Captain', but immortalised in history as 'the Nottingham Captain', was a 31-year old unemployed stocking maker. With his wife and two young children, he had been removed from his home in Sutton-in-Ashfield to his parish of settlement, Wilford, in September 1816, but, finding no room there, came to Nottingham, where he attempted a livelihood by working a stocking-frame. ${ }^{6}$ Having arrived in Pentrich on 5 June with a map and a plan, which he regaled to anyone who would listen, Brandreth assumed leadership of the Rebellion, with fateful consequences for all concerned. During the Rebellion, it was Brandreth's determination to procure 'a man and a gun' at every house and farmstead on route which significantly slowed the rebels progress towards Nottingham, whilst his tactical miscalculations consistently affected their morale and purpose. ${ }^{7}$

\section{[PLEASE INSERT THE MAP Figure 1 NEAR HERE AS A FULL-PAGE]}

Before the rebels had left the vicinity of Pentrich and South Wingfield, a man had been shot and killed. The victim, Robert Walters, was a twenty-one year old servant working for Mary Hepworth on her farm in Wingfield Park. The degree of deliberate intent in Walters' death is still disputed but Brandreth, who carried a pistol in the girdle of his apron, is generally believed to have been

\footnotetext{
${ }^{5}$ For Ludlam, see B. Gregory, Autobiographical Recollections, with Memorials of his Later Life, ed. J. R. Gregory (London: Hodder and Stoughton, 1903), 129; G. P. Moriarty (rev. P. Carter), 'Isaac Ludlam', $O D N B$.

${ }^{6}$ For Brandreth's marriage and children, see Nottinghamshire Archives (NA), PR 9808, PR 9799.

${ }^{7}$ For contrasting views of Brandreth, see J. Belchem, 'Jeremiah Brandreth', ODNB; M. I. Thomis, 'Jeremiah Brandreth', Biographical Dictionary of Modern British Radicals, Volume 1: 1770-1830, ed. J. O. Gossman and N. J. Baylen (Hassocks: The Harvester Press, 1979), pp. 62-4; idem, 'The Nottingham Captain: A Portrait of Jeremiah Brandreth, The Rebel', Nottinghamshire Historian, 14 (Autumn 1974), 7-9.
} 
responsible for it. ${ }^{8}$ In spite of the misgivings raised by this incident, the rebels, now about 100 strong, pressed on to Butterley Ironworks, where they hoped to gain large stores of ammunition. Here, they were confronted by twelve special constables, especially enrolled for the purpose, under the command of the works manager, George Goodwin. Goodwin recognised several of the rebels and lectured them on their folly, telling them, presciently, that they had placed a halter around their necks. In the ensuing stand-off, Brandreth blinked first. The rebels retreated from 'The Battle of Butterley' without making any significant gains. ${ }^{9}$

Heading on by way of Ripley, Brandreth attempted to restore authority and morale amongst the rebels, aided by the arrival of a new contingent of men from Swanwick. But their mood was faltering and heavy rain was beginning to set in. They were fortified with promises of bread, roast beef, plum pudding and rum in Nottingham, 100 guineas for every man and the prospect of pleasure-cruises on the river Trent. More immediately, they took refreshment at no fewer than three public houses in Codnor, refusing to pay the landlords, as their currency would be worthless once the Rebellion had succeeded. ${ }^{10}$ From Codnor, they took the turnpike road to Nottingham, reaching the Navigation Inn at Langley Mill. Here, one of their number, George Weightman, who had gone on ahead to scout out the position in Nottingham, brought them the cheering news that the town had fallen. The officers had refused to turn the soldiers out of the barracks, for fear that they would join the rebels, and nothing would remain to be done when they reached the town. But Weightman was seen in hushed conversation with Brandreth, to some unknown end, and neither man seems to have told the rebels that the information came from second-hand reports rather than first-hand observation. When one of

8 See J. Atkinson, Bravery and Deception: The Pentrich Revolt of 1817 (Nottingham: Nottinghamshire and Derbyshire Labour History Society, 2016), p. 27.

${ }^{9}$ See P. Riden, The Butterley Company, 1790-1830 (Chesterfield: Privately published, 1973), pp. 345.

${ }^{10}$ Gurney, I, p. 360 (testimony from Asbury), p. 427 (testimony from Hole), p. 285 (Codnor). 
the rebels was accidentally shot in the leg, soon afterwards, Weightman volunteered to go off and find a doctor. ${ }^{11}$

By about 7am on Tuesday 10 June, some 60 rebels had reached Eastwood, finding a curiously expectant crowd awaiting their arrival. After departing the Sun Inn, and taking their route down to the Gilt Brook, the rebels spotted, about three-quarters of a mile away, an approaching detachment of $15^{\text {th }}$ Hussars. The troop of twenty men had been despatched from Nottingham Barracks under the command of Captain Frederick Philips, and at the head of them rode two magistrates, Charles Mundy and Lancelot Rolleston. ${ }^{12}$ The sight of twenty Light Dragoons riding towards their position was enough to scatter the rebels in all directions, discarding armaments as they went. All that remained, during the rest of the day, was for the civilian and military authorities to complete their work of search and pursuit either side of the county border. The majority of those seized were taken to Derby Gaol. ${ }^{13}$ However, at 6pm, a waggon and cart brought twenty eight men and a similar number of muskets, seventeen stand of small arms, and four-dozen pikes, into Nottingham for deposit at the County Gaol. The Rebellion was over. ${ }^{14}$

\section{A Nottingham Rising?}

${ }^{11}$ Gurney, I, p. 333, 429, 441; University of Nottingham Manuscripts and Special Collections [UNMASC], East Midlands Collection [EMC], A. Coleman, 'The Pentrich Revolution at Eastwood' (typescript, 1970).

${ }^{12}$ See the depositions of Rolleston, Mundy and Phillips in UNMASC, Ne C 4996/1-6, c.13 June 1817.

${ }^{13}$ See R. A. Gaunt, 'Out and About on the Trail of the Pentrich Rebels', The Historian, 135 (2017), 44-6; UNMASC, EMC, K. R. Clarke, 'The Pentrich Revolution: a modern look at places of interest: photography and text' (typescript, 2008).

${ }^{14}$ T. Bailey, Annals of Nottinghamshire (London: Simpkin, Marshall and Company, 1853), IV, p. 296; UNMASC, Ne C 4995/2, lists those apprehended on 10 June 1817. 
The Pentrich Rebellion has traditionally and understandably been recognised as a 'Derbyshire Rising', 'the Last Revolution in England' and, for all its rebelliousness, a considerable source of local pride. This was the spirit which animated the $150^{\text {th }}$ anniversary commemorations of the Rebellion, in 1967, and was much in evidence during the bicentenary commemorations in the summer of $2017 .{ }^{15}$ However, history transcends county boundaries. This article re-considers Nottingham's role in the events immediately preceding the Rebellion, as well as its reaction on the night of 9-10 June, in the light of two continuing areas of historiographical debate.

Nottingham's centrality to the Rebellion has been a matter of active interest for historians since the 1960s. For Thompson, Pentrich represented 'one of the first attempts in history to mount a wholly proletarian insurrection, without any middle-class support', and thought it significant that it was centred in one of the districts 'in which the secret Luddite organization had been strongest'. ${ }^{16}$ The town had a well-established reputation for radicalism and had already achieved national notoriety through its central place in Luddism. However, the degree to which Nottingham was a radical, rather than a revolutionary, town, has continued to be debated since Thompson. ${ }^{17}$ As I have argued elsewhere, Nottingham's ambivalent reaction to the Battle of Waterloo in 1815 was a consequence of the town's war-weariness after a generation spent fighting the armies of Revolutionary and Napoleonic France and disillusionment at the meagre offerings which accompanied the return of

${ }^{15}$ For the $150^{\text {th }}$ anniversary commemorations, see J. Sinar (compiled), The Pentrich Revolution 1817 (Ripley: G. C. Brittain, 1967). For the bicentenary commemorations in 2017, see 'Pentrich Rising Bicentenary Special' <https://www.youtube.com/watch?v=4vyXj2aarCY $>$ [accessed July 1, 2018].

16 Thompson, pp. 719, 733.

${ }^{17}$ Initially by M. I. Thomis, Politics and Society in Nottingham, 1785-1835 (Oxford: Blackwell, 1969), and subsequently by, for example, J. V. Beckett, 'Responses to War: Nottingham in the French Revolutionary and Napoleonic Wars, 1793-1815', Midland History, 22 (1997), 71-84. 
peace, rather than an example of its revolutionary intentions. ${ }^{18}$ The Pentrich Rebellion fell one week short of Waterloo's second anniversary, on 18 June, at a time of renewed social and political tension in the town. Why did trouble fail to materialise in Nottingham on the night of the Rebellion, given the genuinely conflicting evidence regarding the revolutionary potential of Nottingham? As the ultimate goal and destination for the rebels, the town loomed large in their thinking, affecting the course and outcome of the Rebellion.

The connection between Luddism and the Pentrich Rising has also proved contentious. Thompson noted the close chronological and geographical affinity between the two events but Thomis subsequently argued against regarding Pentrich as the 'Last Luddite Revolt'. Subsequent explorations of Luddism have failed to establish a definitive connection between the two movements but, rather, to reinforce John Dinwiddy's contention that there was a 'degree of continuity' between Luddism and the Rising. Though some of the Nottingham men most associated with Luddism (like Gravenor Henson and Francis Ward) successfully repelled government attempts, after the Rebellion, to implicate them in the conspiracy, there were undoubtedly shared points of contact between the Nottingham radicals and the Pentrich Rebels. ${ }^{19}$ As it will be argued below, the Rebellion was heavily influenced by the work of a secret committee centred on Nottingham, the North Midlands Committee. It was the ability with which the Home Office and local magistrates were able to infiltrate this

${ }^{18}$ R. A. Gaunt, 'Nottingham and the Great Peace, Reflections on the end of the Napoleonic Wars', Midland History, 41 (2016), 20-36.

${ }^{19}$ F. K. Donnelly, 'Ideology and Early English Working-Class History: Edward Thompson and His Critics', Social History, 1 (1976), 219-38; J. R. Dinwiddy, Radicalism and Reform in Britain, 17801850 (London: Hambledon Press, 1992), p. 374; J. Atkinson and R. Tanner, Luddism in the East Midlands: Riots and Negotiations (Nottingham: Nottinghamshire and Derbyshire Labour History Society, 2018), pp. 44-6. See below, note 80 . 
committee and be kept informed of its plans which proved crucial to their preparedness on the night of 9-10 June..$^{20}$

It was also a Rebellion led by a Nottingham man - Jeremiah Brandreth. Indeed, were it not for the close connections between the Pentrich men and the Nottingham committee, Brandreth would hardly have been fastened on as the leader of the Rebels, for there was no other practical or personal reason why he would have done so. Brandreth's leadership of the Rebellion was used after the event to explain away the participation of other men. Had it not been for the 'Nottingham Captain', they said, the Derbyshire men would not have risen. However, whilst Nottingham's reputation for radicalism was a convenient alibi for their county neighbours, it obscured the fact that, thanks to the actions of the Corporation as well as the secret intelligence available to them, the chances of a successful rising in Nottingham were always much lower than the rebels anticipated. ${ }^{21}$

\section{Nottingham in 1817}

The Lord Lieutenant of Nottinghamshire, the $4^{\text {th }}$ Duke of Newcastle, received news of the Rebellion's defeat with unalloyed joy. He was particularly moved by the fact that the country people in Nottinghamshire had failed to mobilise in their support. 'This is a spirit to be carefully encouraged', he told Rolleston, 'it is the only constitutional and permanently effectual means of resisting disaffection'. Newcastle proceeded to issue a proclamation which amounted to little more than a homily on the virtues of the existing constitution and praising those who 'manfully, courageously and like HONEST ENGLISHMEN resisted all the endeavours...used to...compel them to make common cause with these desperate villains'. The county magistrates were so taken with the Duke's prose that,

\footnotetext{
${ }^{20}$ S. Wilkes, Regency Spies. Secret Histories of Britain's Rebels \& Revolutionaries (Barnsley: Pen and Sword, 2015).

${ }^{21}$ The branding of Brandreth can be traced from the depositions, by way of the trials: UNMASC, Ne C 4995/1-14, Examinations taken before Dr Charles Wylde, 13 June 1817; also see notes 68 and 78 below.
} 
in addition to its publication in the Nottingham press, it was issued as a short-run pamphlet and distributed to villages in the disturbed districts. The Corporation of Nottingham was equally attentive to winning the propaganda war, spending money on public notices, including broadsides detailing the history of the Rebellion and its aftermath. ${ }^{22}$

Newcastle's satisfaction at the course of events was understandable, given the almost constant sense of vigilance which animated the civilian authorities in town and county alike in the years preceding the Rebellion. Newcastle's relief at the quiescent state of the villages surrounding Nottingham was undoubtedly motivated by his appreciation of the fact that Luddism had been as much a phenomenon of the Nottinghamshire countryside as of Nottingham itself. ${ }^{23}$ Exactly one year before the Rebellion, on 9 June 1816, the newly-appointed Deputy Recorder of Nottingham, and rising star of the legal world, Thomas Denman, defended the Luddites Thomas Glover and John Chettle for an attack on William Wright's house at New Radford. This resulted in damage to a dozen frames but public sympathy was on the side of the defendants. The two men were acquitted two months later, but, such

22 For Newcastle's address, UNMASC, Ne C 4974, Newcastle to Rolleston, 11 June 1817; Ne C 4990, Newcastle's draft address; Ne C 4988, Charles Wylde to Newcastle, 13 June 1817; Nottingham Review, 13 June 1817. Sidmouth commended the address as 'particularly judicious': TNA, HO 42/166, ff. 190-191, Sidmouth to Newcastle, 14 June 1817. Also see, UNMASC, Not 3.F19 NOT EM S-C Oversize X Nottingham, 'Particulars of the late Treasonable Conspiracy and Rebellion', 15 June 1817; Records of the Borough of Nottingham, VIII: 1800-1835 [RBN] (Nottingham: Thomas Forman and Sons, 1952), p. 223.

${ }^{23}$ See M. I. Thomis, The Luddites (Newton Abbot: David and Charles, 1970), appendix; M. Roberts, 'Rural Luddism and the makeshift economy of the Nottinghamshire Framework Knitters', Social History, 42 (2017), 365-98. 
was the public interest in the case, there was widespread concern that the judge and jury might have been attacked - or even assassinated - if they had not been acquitted. ${ }^{24}$

These events clearly influenced the Home Secretary, Viscount Sidmouth, when he subsequently informed Newcastle that the spring assizes for Nottinghamshire, in March 1817, would be heard at Newark instead of Nottingham. Newcastle found himself in the - for him, unusual - position of defending the honour of the county town, protesting that it would leave an impression that 'Justice is not Sufficiently Strong, \& that the disaffected have carried their point'. Newcastle told his fellow magistrate, William Sherbrooke, that it was 'right to make this representation for the honor of the Magistracy and loyal inhabitants of this County'. Sidmouth's decision was subsequently reversed. ${ }^{25}$

Throughout the first half of 1817 , county magistrates and town authorities were united in representing the peaceful state of Nottingham to the Home Office in London. Minds were focused, in this respect, by the unhelpful references to Nottingham contained in the 'Report of the Committee of Secrecy', issued by the House of Commons in February 1817. The 'Report' was a response to an attack on the Prince Regent's coach, at the State Opening of Parliament, in January. It was a detailed attempt by the government to demonstrate the unsettled state of the country, providing the pretext for passing the socalled 'Two Acts', which further defined the meaning of Treasonable Practices and restricted the calling of Seditious Meetings, using the precedents established during the wars with Revolutionary France in the 1790s. With parliament's approval, the government also suspended habeas corpus for

${ }^{24} \mathrm{H}$. Field, The Date-Book of Remarkable and Memorable events connected with Nottingham and its neighbourhood, 850-1884 (Nottingham: Henry Field, 1884), pp. 305-6; RBN, p. 211; Bailey, pp. 27982.

${ }^{25}$ UNMASC, Ne C 4936, Sidmouth to Newcastle, 25 February 1817; Ne C 4929, Newcastle to Sidmouth, 27 February 1817; Ne C 4937, Sidmouth to Newcastle, 28 February 1817; Ne C 4981, Newcastle to Sherbrooke, 28 February 1817. For Newcastle's troubled relations with Nottingham, see R. A. Gaunt, 'Neighbours from Hell? The Fourth Duke of Newcastle and the people of Nottingham in the early nineteenth century', Transactions of the Thoroton Society, 104 (2000), 99-112. 
one year, allowing it to hold anyone for extended periods, on a warrant from the Home Secretary, without bringing them to trial. ${ }^{26}$

According to the committee's 'Report', Nottingham was one of the towns which was seething with 'clubs, associated professedly for the purpose of parliamentary reform, upon the most extended principle', which really provided a cover for revolutionary objects. Rolleston and Newcastle contested these claims vigorously, disclaiming any notion that Nottingham was in league with such associations in Manchester, whilst a public meeting in Nottingham protested against 'the dangerous and unconstitutional procedure of suspending the liberties of the people, on vague and ex parte information' ${ }^{27}$ Rather than quelling an incipient revolt, the government's actions probably served to fuel one. Looking back on this period, the following year, the leading Nottingham radical, William Stevens, recalled that 'as there was now no safety for any man...the time to resist was come, seeing that the Fundamental Laws of the Country were subverted'. ${ }^{28}$

There were certainly sufficient grounds for considering Nottingham a troubled town in this period. In addition to the Luddite disturbances, the town was affected by spiralling prices for basic foodstuffs. Wheat averages, which stood at $63 \mathrm{~s} 8 \mathrm{~d}$ a quarter in 1815 , had risen progressively to $76 \mathrm{~s} 2 \mathrm{~d}$ a quarter in 1816 before peaking at $94 \mathrm{~s}$ in 1817.1816 was 'the year without a summer', caused by the aftereffects of the eruption of Mount Tambora in Indonesia. The harvest was as bad as the summer was cold. Harvest failure fed poverty and bred distress. The poor rate, which had quadrupled by 1812 ,

\footnotetext{
${ }^{26}$ For the government's use of 'repressive' legislation, see P. Harling, 'The law of libel and the limits of repression, 1790-1832', Historical Journal, 44, (2001), 107-134, and C. Emsley, 'Repression, terror and the rule of law in England during the decade of the French Revolution', English Historical Review, 100 (1985), 801-26.

27 'Report of the Committee of Secrecy' in Parliamentary Debates, 35 (1817), cols. 438-447 (quotation at 443); UNMASC, Ne C 4970, Rolleston to Newcastle, 6 April 1817; Ne C 4931, Newcastle to Sidmouth, 8 April 1817; Bailey, p. 289.

${ }^{28}$ William Stevens' deposition in Cobbett's Weekly Political Register, 16 May 1818.
} 
came under renewed stress. Parishes responded with the strict enforcement of settlement orders, such as the one served on Jeremiah Brandreth in September 1816, as an attempt to shift the burden of responsibility and lessen the demands being placed upon them. ${ }^{29}$

Against this volatile backdrop of economic distress must be set the vigilance and wise policy of the Corporation of Nottingham. The Corporation had long been known for its Whig and Nonconformist sympathies and its willingness to stand-up against the activities of the Tory government in London. Not only did it encourage the expression of political discontent, during this period, through open public meetings, but kept its expression within safe boundaries by promoting petitions in support of such popular causes as the abolition of Income Tax, the reduction of the peacetime military establishment and the promotion of parliamentary reform. This was the outcome of the Corporation's political sympathies as well as its pragmatism. ${ }^{30}$

Nor did it neglect to take a lead in assisting the destitute poor. In December 1816, at a numerouslyattended public meeting at the Town Hall, it pledged 100 guineas to a relief fund. Lord Middleton followed suit, offering 300 tons of coal, and the Parish of St Nicholas pledged $£ 500$ towards instituting a soup-kitchen. ${ }^{31}$ By May 1817, barely a month before the Pentrich Rebellion, it was possible for one of Sidmouth's better-informed local correspondents to assure him that public tranquillity reigned in Nottingham; no anti-government meetings had been held; no seditious

\footnotetext{
${ }^{29}$ Bailey, pp. 278, 287, 299; NA, M24038, Brandreth's removal order, 12 September 1816; W. K. and
} N. P. Klingaman, The Year Without Summer: 1816 and the Volcano that Darkened the World and Changed History (New York: St Martin's Press, 2014).

${ }^{30} R B N$, pp. 205, 214; Bailey, pp. 282-283, 287-288; Field, pp. 306, 310.

${ }^{31}$ RBN, p. 213; Field, p. 309. For the soup and coal distributed, see Nottingham Review, 21 November 1817. 
publications were in circulation; there were funds for the relief of the destitute poor and the bobbin net trade was improving. ${ }^{32}$

Equally telling is the fact that neither Newcastle nor the county magistrates were in favour of extending the provisions of the Watch and Ward Act. The legislation, first passed in 1812 as a reaction to the Luddite disturbances in Nottingham, allowed for all men over the age of seventeen to patrol their wards in parties of 25 , in order to guard against trouble. ${ }^{33}$ There were penalties (ranging from £2-10) for anyone who failed to serve. The act had been renewed from 1 July 1816 and been used energetically during the winter but, as it approached its expiration in the spring, no-one (aside from Sidmouth) felt the situation justified its extension. As William Sherbrooke observed to Newcastle, on 15 April:

It is the determination of the Magistrates to pray every possible attention to the preservation of the public peace \& to watch over it with the greatest vigilance \& altho' I am peculiarly partial to the enforcement of the Watch \& Ward act at proper times yet I must express my conviction to your Grace that it would be good policy to discontinue it at this time. ${ }^{34}$

\section{Nottingham on 9-10 June 1817}

\footnotetext{
${ }^{32}$ TNA, HO 42/165, ff. 101-3, James Lyon to Sidmouth, 13 May 1817.

${ }^{33}$ Field, Date-Book, p. 309; Brandreth was amongst those who served: NA, CA 1490a, ff. 107, 122.

${ }^{34}$ UNMASC, Ne C 4979, Sherbrooke, to Newcastle, 6 April 1817; Ne C 4931, Newcastle to Sidmouth, 8 April 1817; Ne C 4942, Sidmouth to Newcastle, 11 April 1817; Ne C 4980, Sherbrooke to Newcastle, 15 April 1817. For its use during the winter, see Ne C 4951, A. H. Eyre to Newcastle, 3 November 1816; Ne C 4952, Edward Smith Godfrey to Newcastle, 3 November 1816 and Ne C 4975, Major-General Henry Fane to William Sherbrooke, 3 November 1816.
} 
Nottingham failed to rise in support of the Pentrich Rebellion on the evening of 9 June. Reports after the event suggested that there was some heightened sense of anticipation in the town, but the largest concentration of men was on the Forest, the assigned meeting point for the Rebels, where 100 men gathered under the lead of John Brown, alias George Jackson, a former soldier and member of the Belper militia. William Roper, who lived at the Stand, near the Race-Course, stated that the men stood in line 'two deep, and part of them armed with either poles or pikes'. Roper made his way through them and went home, when he:

observed about the same number of armed men form into a line, under the piazzas and shed of the building. Knocking at the door, they demanded the arms of which they supposed the Stand was a depot, but Roper assuring them that there [was] only a rifle and a fuzee [or explosive fuse] in his custody, the men, after some further parleying, withdrew, and nothing further occurred. ${ }^{35}$

The Nottingham authorities were in a heightened state of vigilance on 9-10 June. They enrolled nearly 500 special constables during this period and the town magistrates sat through both nights at the police office, which was located in the Exchange Building in Market Square. The Holme and Newark troops of Yeomanry Cavalry also remained in a state of readiness. ${ }^{36}$ The Town Clerk, Henry Enfield, had it on good authority that the plan had been for men to gather together before dark at Basford and for groups from Arnold, Hucknall and Bulwell to get hold of the arms and horses of the Bunny Yeomanry Cavalry. According to Enfield's source, Mansfield and Sutton were to rise about 9pm, reach Bulwell by $10 \mathrm{pm}$ and then move on to Nottingham, which was to rise at $11 \mathrm{pm}$. This schedule is confirmed by William Roper's report, which said that the men had congregated on the Forest at around $11.30 \mathrm{pm} .{ }^{37}$

\footnotetext{
${ }^{35}$ Bailey, Annals, 295; Field, Date-Book, 319-20. For Roper, see Gurney, I, pp. 161-76, 462-6.

${ }^{36} R B N$, p. 223; Field, pp. 319-21; UNMASC, Ne C 4972, Robert Leeson to Newcastle, 10 June 1817.

${ }^{37}$ TNA, HO 42/166, f. 55, Henry Sampson to Henry Enfield, 5 June 1817.
} 
What Enfield also knew, but could not rely upon, was the apathy expressed by those men who might otherwise have rallied to the rebels. On 6 June, William Stevens was informed of the difficulty of recruiting rebels at Bulwell and Arnold and the reason why: 'they had witnessed so much disaster, in coming forward in mobs, that they would not stir until they knew proper arrangements had been made as to leaders and organisation'. Events bore out these reports. As John Need subsequently told Newcastle: 'at Mansfield there was no appearance of assembling, at Sutton a party assembled but not so numerous as was expected (not more than forty) [and] the respectable inhabitants were very active'. By 12 June, Enfield could inform Sidmouth that 'the most perfect Tranquillity now prevails in this neighbourhood - There was not throughout Yesterday any appearance unfavourable to the public Peace'. Yet the second 'Report of the Committee of Secrecy', issued on 20 June, maintained that Nottingham was targeted by the rebels 'in expectation... of finding that place in full insurrection and prepared to support them'. ${ }^{38}$

\section{Spies and Rebels}

By the time that parliament discussed the 'Report', Edward Baines, the editor of The Leeds Mercury, in one of the most sensational journalistic scoops of all time, exposed the activities of 'Oliver the Spy'. The revelations completely altered the way in which the Pentrich Rebellion was viewed, and undermined the government's attempt to present it as a popular insurrection. ${ }^{39}$ Newspapers which had struggled to contain their shock, incredulity and condemnation, shortly after the Rebellion, now began

\footnotetext{
${ }^{38}$ TNA, HO 42/166, ff. 139-140, Sampson to Enfield, 6 June 1817; f. 431, Enfield to Sidmouth, 12 June 1817; UNMASC, Ne C 4962, John Need to Newcastle, 10 June 1817; 'Report of the Committee of Secrecy' in Parliamentary Debates, 36 (1817), cols. 1088-98 (quotation at 1095).

${ }^{39}$ For the exposure of Oliver, see The Leeds Mercury, 14 June 1817; D. Thornton, Mr Mercury. The Life of Edward Baines 1774-1848 (Cardiff: Merton Priory Press, 2009), pp. 100-16.
} 
to revise their earlier opinions, as more revelations began to emerge about the extent of government 'involvement' in the affair. ${ }^{40}$

Oliver was the most frequently used of the aliases of William John Richards, a forty-three year old carpenter and builder from Shropshire who had fallen on hard times. In March 1817, on quitting debtors' prison, Richards offered his services to Sidmouth as a government informer and, soon afterwards, successfully inveigled himself into the network of radical clubs and societies campaigning for an extensive parliamentary reform. ${ }^{41}$

The network centred on the Hampden Clubs, whose figurehead was Major John Cartwright, the Nottinghamshire-born reformer and veteran of political campaigns going back to the struggle for American Independence. The clubs, which were named after the Civil War martyr John Hampden, were initially founded in 1812 but expanded considerably in the period after 1816 . They campaigned for universal suffrage, secret ballot, annual parliaments and equal electoral districts - causes which animated reformers throughout the first half of the nineteenth century. ${ }^{42}$ The first club to be established outside London was in Lancashire in 1816, with some 150 operating in the Midlands and North by the following year. Locally, there were Hampden clubs at Chilwell, Beeston and Arnold, all of which were within a few miles of Nottingham. ${ }^{43}$

\section{[INSERT ILLUSTRATION Figure 2 HERE PLEASE - PREFERABLY FULL PAGE]}

\footnotetext{
${ }^{40}$ For the original tone, see Nottingham Review, 13 June 1817.

${ }^{41}$ See M. Chase, 'W.J. Richards [alias William Oliver; called Oliver the Spy]', ODNB, and A. F. Hattersley, Oliver the Spy and Others: A little Gallery of South African Portraits (Cape Town: Maskew Miller, 1959), pp. 1-25.

${ }^{42}$ N. C. Miller, 'John Cartwright and Radical Parliamentary Reform, 1808-1819', English Historical Review, 83 (1968), 705-28; idem, 'Major John Cartwright and the founding of the Hampden Club', Historical Journal, 17 (1974), pp. 615-19.

${ }^{43}$ The Nottingham Hampden Club met at The Golden Fleece on Drury Hill (Middle Pavement).
} 
A national meeting of delegates was held at the Crown and Anchor tavern in London in January 1817, chaired by Cartwright and addressed by the leading radical campaigners Henry Hunt and William Cobbett. However, the meeting exposed divisions within the reform movement about how extensive a reform they should seek and whether they should confine themselves to petitioning parliament. A few days later, the Prince Regent's coach was attacked. The following month, the Committee of Secrecy issued its 'Report', specifically targeting the clubs as hotbeds of sedition, and the government legislated for the suspension of habeas corpus and the proscription of meetings convened for political purposes. It was as a result of these events that bodies such as the North Midlands Committee emerged as key reference points for local radicals. ${ }^{44}$

Into this situation stepped 'Oliver the Spy'. Through his association with Charles Pendrill, a Londonbased boot and shoe maker, Oliver was admitted into the acquaintance of Joseph Mitchell, a draper and leading reformer from Liverpool. On 23 April, Oliver and Mitchell set out on a tour of the northern industrial districts to assess the state of the reform movement. During the course of the next month, they visited towns including Birmingham, Derby, Sheffield, Wakefield, Dewsbury, Leeds, Manchester and Nottingham. Oliver assumed the status of 'the London Delegate' - a title which allowed him to represent himself as all things to all men. Sometimes he presented himself as the sober emissary of the Hampden Clubs, endorsed by the radical MP Sir Francis Burdett. At other times, he was the hot-headed zealot, agitating men to abandon the petitioning of Parliament in favour of direct action. $^{45}$

The pivotal moment was a meeting at Wakefield on 5 May, where Oliver made a speech in front of about a dozen delegates and promised the support of 70,000 men in London. News reached the meeting that Mitchell had been arrested the day before, about three miles from Huddersfield, leaving the field clear for Oliver. Plans were then set in train for a rising to take place on Whit Monday, 26

44 'Report of the Committee of Secrecy' in Parliamentary Debates, 35 (1817), cols. 438-47.

${ }^{45}$ Oliver's role during this period was extensively reviewed after the event: see Parliamentary Debates, 37 (1818), cols. 353-63. 
May 1817. According to Oliver's account, over 200,000 men were to be mobilised for the occasion, with Birmingham contributing 150,000, Sheffield 10,500, Leeds 10,000, Huddersfield 8,000, Barnsley 5,000, Wakefield and Dewsbury 2,500 and the East Midlands some 30,000. ${ }^{46}$

It was at the Wakefield meeting that Oliver first met Thomas Bacon, the 63-year old delegate of the East Midlands reformers. Bacon had impeccable credentials as a revolutionary, having gained a reputation for extreme radical views since the French Revolution of 1789. In 1801, whilst working in the West Midlands, he was denounced 'on account of his Disloyal Principles \& being supposed to be connected with the Corresponding Societies'. However, other evidence from this period testifies to his 'perfectly steady, Honest \& Industrious' character and maintained that he had been subject to malicious reports against him. This may explain the willingness of the Duke of Devonshire's agents at Pentrich to allow him to continue the tenancy of his parents' farm in the village after their deaths. ${ }^{47}$ After Waterloo, Bacon helped to establish Hampden Clubs at Pentrich, Ripley and Alfreton and was a leading delegate for the East Midlands region. A framework knitter and iron-dresser by trade, 'Old Tommy', as he was called, was as distinctive in his appearance as his political views. The Lancashire reformer Samuel Bamford, who met Bacon during this period, recalled him as:

an aged grey-headed man, stooping beneath probably seventy years; his venerable locks, hanging to his shoulders, and having in one hand a stick, and on the other arm a basket containing rolls of worsted and woollen yarn, and small articles of hosiery which he seemed to have for sale.

\footnotetext{
${ }^{46}$ TNA, HO 40/9/2, Oliver's contemporary account of his travels.

${ }^{47}$ Chatsworth House Archives, Derbyshire, AS 1293/1. I acknowledge the Trustees, Chatsworth House Settlement (by permission of the Duke of Devonshire), for permission to reproduce material from the Devonshire Collection.
} 
As Thomis notes, Bacon was 'an incorrigible traveller and the epitome of the itinerant delegate who did so much amongst the radicals of the day to foster the illusion that they possessed strength and organisation' ${ }^{48}$

Oliver came to Nottingham three times, over the course of the next two months - on 15 May, 26 May and 7 June - but historians have failed to establish whether he ever met Brandreth. ${ }^{49}$ This is important because, from the time The Leeds Mercury exposed Oliver's activities, there has been an on-going debate about whether Oliver exceeded his remit as an informer, by acting as an 'agent provocateur' who actively stirred up events leading to the Rebellion. In simple terms, the argument goes, Oliver duped Brandreth and Brandreth, in turn, duped the unsuspecting villagers of Pentrich. ${ }^{50}$

Thompson attributed the failure of the Pentrich Rebellion to the interference of Oliver, arguing that, but for him, the rebels might well have achieved greater success. The problem is a difficult one for historians to answer with certainty for, as Reginald White observed, during the same period:

it is easy to see...how the intrusion of an unscrupulous agent like Oliver into the complex of clubs and delegates could lead to panic on the one hand and delusion on the other, until the

${ }^{48}$ S. Bamford, Passages in the Life of a Radical (New York: Augustus M. Kelley, 1967), I, pp. 156-7; M. Thomis, 'The Guilt of Thomas Bacon of Pentrich', Derbyshire Archaeological Journal, 94 (1974), 41.

49 Thompson, p. $721 \mathrm{n} .1$, suggests that Brandreth and Oliver did meet, but the evidence only establishes that Oliver met the Nottingham committee men - Brandreth's attendance at that meeting is still in doubt.

${ }^{50}$ Parliamentary Debates, 37 (1818), cols. 338-95. The case for the defence appears in cols. 19-56. Also see A. F. Fremantle, 'The Truth about Oliver the Spy', English Historical Review, 47 (1932), $601-16$ 
whole situation between governors and governed assumed the malevolent aspect of a diabolically contrived mechanism. ${ }^{51}$

In the wake of his exposure in the Leeds Mercury, journalists and Whig MPs campaigned for an inquiry into Oliver's role, accusing the government of using him to 'excite people to illegal acts, for the purpose of entrapping them'. Charles Sutton, editor of the Nottingham Review, also took up the case, publishing his evidence about Oliver's activities on the same day that Brandreth was executed for his part in the Pentrich Rebellion. ${ }^{52}$

However, whilst uncertainty remains in the matter of Oliver and Brandreth, historians can readily trace the interactions between Oliver and the network of Nottingham radicals who met in the weeks leading up to the Rebellion. The North Midlands Committee, under the leadership of William Stevens, met in a variety of private homes and public houses in the town. The Committee was looked to for leadership within a fifteen mile radius of Nottingham; a fact which explains the strong gravitational pull between the town and the villages at the heart of the Pentrich Rebellion. ${ }^{53}$

The leaders of that Rebellion, Brandreth, Ludlam, Turner and Bacon, were all associated with the North Midlands Committee, but, unbeknown to them, the Town Clerk of Nottingham, Henry Enfield, had his own informer on the inside. This was Henry Sampson, a framework knitter and father of six living in Bulwell, four miles from Nottingham. Enfield's predecessor as clerk, George Coldham, had

${ }^{51}$ E. P. Thompson, 'God and King and Law', The New Reasoner, 3 (1957-58), 69-86, reviewing R. J. White, Waterloo to Peterloo (London: William Heinemann Ltd, 1957). The quotation is from R. J. White, 'The Pentrich Revolution, 1817', History Today, 5 (1955), p. 540.

${ }^{52}$ Sir Francis Burdett in Parliamentary Debates, 36 (1817), cols. 1016-23; Nottingham Review, 7 November 1817.

${ }^{53}$ Stevens was a needle-maker living at King's Square, off Woolpack Lane. See Atkinson, Bravery and Deception and J. D'Arcy, 'Framework Knitting in the Parish of Alfreton, 1670-1870', Derbyshire Archaeological Journal, 137 (2017), 164. 
paid $£ 22 \mathrm{~s}$ a week for information at the height of the Luddite disturbances in 1812. It is likely that Sampson was receiving an equivalent sum for his information. Thus, it is in Sampson's reports to Enfield that we find details of the local situation in Nottingham in the run-up to the Pentrich Rebellion, including references to Oliver. Such was the sensitivity with which the Home Office protected the identity of its informants, that neither Enfield nor Sampson knew that Oliver was a spy. ${ }^{54}$

Consequently, due allowance needs to be made for the fact that our knowledge of this period derives, on the one hand, from the evidence of a paid informer, and, on the other, from depositions given by men like William Stevens after the Rebellion had failed and Oliver's role had been exposed. The former might be guilty of exaggeration before the fact, and the latter of exaggeration after it. Nevertheless, Sampson's reports prove most instructive for the period from 23 May-7 June, when Oliver was engaged in his second tour of the northern districts, during which he was introduced to the North Midlands Committee at Nottingham. This was the time when, according to Thompson, 'Oliver acted like a man with a quite different brief' from that of a mere informer. ${ }^{55}$

Oliver's most substantial connection with the committee followed his arrival in Nottingham on Monday 26 May, the date originally proposed for the uprising. Sometime previously, he had suggested that the Rebellion be postponed. There was some discussion of moving it to 4 June, when the soldiers would be drunk on the rations distributed to them on the King's birthday, before 9 June was settled on, because the new moon would enable the rebels to act with less fear of detection. So, instead of rebelling on the evening of Whit Monday, Oliver attended a meeting convened at Stevens' house, where he was introduced to a select gathering of local radicals by James Birkin, the Derby

\footnotetext{
${ }^{54}$ Thomis, Politics and Society, pp. 77-99. Enfield succeeded as Town Clerk after Coldham's death in 1816.

55 Thompson, Working Class, p. 718. Sampson's reports are cited below, notes 58, 60. For Stevens, see note 28 above.
} 
delegate. Thus vetted and initiated into their counsels by a trusted individual, Oliver then proceeded to a meeting of the secret committee at the Three Salmons. ${ }^{56}$

Oliver left Nottingham shortly afterwards and, by the time that he returned to Nottingham, on Saturday 7 June, the situation had been transformed. A few days before his arrival, the relationship between Nottingham and Pentrich had been determined when it was decided that the Pentrich Rebels were to come to the assigned meeting place on the Forest, rather than the Nottingham men to travel in the other direction and meet them at Butterley Ironworks. The rationale for this was later summed up by Thomas Bailey:

The people in London would not be satisfied unless Nottingham was perfectly secured, for it was the rallying point for Nottinghamshire, Derbyshire, and Leicestershire; and that if it was not secured the passage over the Trent would be perfectly stopped to the northern forces. $^{57}$

Whether it was this decision which finally gave Thomas Bacon cause to pause, the man described as the 'Nestor of the Derbyshire Reformers', now had second thoughts about the Rebellion. He informed Stevens that he could not risk participation, as Sidmouth had a warrant out for his arrest. With habeas corpus suspended, and no immediate prospect of trial or release, he lived in fear of his life. Consequently, on Thursday 5 June, Bacon returned to Pentrich with Brandreth, a man well-known to him through meetings at the North Midlands Committee. He was introduced to the villagers as the man best placed to lead them in the coming struggle. Before leaving for Pentrich, Brandreth met Henry Sampson at The Leg of Mutton. There, Sampson learned that Brandreth 'was going to [Pentrich] for good to command the men who were to rise there and that he was to bring them here and Bacon with them and to collect from all the Towns they came through'. Sampson also saw Ann

\footnotetext{
${ }^{56}$ Parliamentary Debates, 37 (1818), col. 356. Birkin died the following year, aged 26, 'one of the victims to the system of espionage and cruelty': Monthly Magazine, 45 (1818), p. 284.

${ }^{57}$ Bailey, p. 293.
} 
Brandreth, who was expecting the couple's third child. She told Sampson that she did not expect her husband to return home until 'the business was finished' ${ }^{58}$

Two days after Brandreth's departure for Pentrich, Oliver arrived in Nottingham for the final time. Events were now closing in on him. Ten of the Yorkshire radicals, the day before, had been lured to a meeting at The Sportsman's Arms at Thornhill Lees near Wakefield. The authorities, duly informed, had moved in and arrested them all. However, Oliver, who was taken alongside them, was released soon afterwards. On being questioned about this, by a local contact, Oliver raised further suspicions about his role. By the time that he arrived at the Blackamoor's Head in Nottingham, under the name 'Hollis', questions were afoot, feelings were high and some of the Nottingham radicals were minded to shoot him as a spy. ${ }^{59}$

Whatever else might be said about Oliver's character and conduct, during this period, it says something for his personal courage that, knowing this to be the case, he willingly attended a meeting of Nottingham radicals at the Punch Bowl on Barker Gate at 9pm that evening. To do otherwise would have confirmed the suspicions concerning him and, in all likelihood, stayed the hand of the rebels. During a heated meeting, he was questioned by up to twenty men about his movements, before being allowed to leave. According to Sampson, who remained ignorant as to Oliver's true identity, one of his accusers apologised for his treatment at their hands - 'but there are many working for the Government - you are an entire stranger to me \& may be one for ought I know'. The next day, Oliver left Nottingham, calling in on the Birmingham radicals, as planned, on his return to London. ${ }^{60}$

Whilst Oliver was desperately seeking to maintain his incognito and Brandreth was scouting the district around Pentrich, the Nottingham authorities were preparing in earnest for the night of 9 June.

\footnotetext{
${ }^{58}$ TNA, HO 42/166, ff. 54-5, Sampson to Enfield, 5 June 1817. Brandreth's daughter Mary was baptised in 1818: NA, PR 9799.

${ }^{59}$ Wilkes, pp. 127-36.

${ }^{60}$ TNA, HO 42/166, ff. 419-20, Sampson to Enfield, 7 June 1817.
} 
At midnight on 8 June, Sidmouth was informed, with remarkable accuracy, by the military commander of the district, that the 'rising of the disaffected' would take place between 9pm and 10pm the following day. Men were expected to come from the north-east of Nottinghamshire and from Derbyshire and 'to attack in small parties the houses where soldiers are quartered with a view of getting possession of their arms'. The following night, with the Rebellion underway, two Nottingham magistrates wrote to the Home Office, naming seven men, including Thomas Bacon, William Stevens and Jeremiah Brandreth, as 'engaged in treasonable practices against His Majesty'. ${ }^{61}$ But the authorities had been fully apprised of these plans, and aware of these men, for some time. As Newcastle subsequently told Sidmouth:

The plot had been hatching for some time, which we knew, and were prepared accordingly. We thought it much more desirable to let the matter come to a Crisis, than to endeavour to crush it before the Designs were openly disclosed. ${ }^{62}$

\section{Trial and Retribution}

The fate of the Pentrich Rebellion was determined by the amount of knowledge which the government and local magistrates had amassed, the preparations of the civil and military authorities to meet it and the unwillingness of potential rebels to act without some sure guarantee of success. By contrast, Jeremiah Brandreth's doom was sealed by an entirely unpredictable twist of fate.

Having escaped the Light Dragoons at Gilt Brook, on the morning of Tuesday 10 June, Brandreth made for Bristol, where he twice boarded, and was turned off, ships destined for the United States. Returning to Nottinghamshire, he was re-united with his wife at her father's house in Sutton. But with a 50 guinea reward on his head, he needed a safe house in which to hide. Where better than the home of his old friend and fellow committee-member Henry Sampson? When two gamekeepers

${ }^{61}$ TNA, HO 42/166, ff. 149-50, James Lyon to Sidmouth, 8 June 1817; f. 410, Charles Morley and John H. Barber to Sidmouth, 9 June 1817.

${ }^{62}$ Stevens, p. 60. 
subsequently called at the house, in Bulwell, under the pretence of searching for snares, they proceeded to take the biggest catch of their lives. ${ }^{63}$

'The Nottingham Captain' now took his trial, alongside William Turner, George Weightman and Isaac Ludlam senior, at the County Hall in St Mary's Gate, Derby. Though Thomas Bacon's name stood first on the indictment, he had played no part in the actual Rebellion. Moreover, as the government well knew, Bacon provided the only certain link with Oliver, whose activities would be sure to come out if he was examined in open court. Oliver's exposure had already affected the government's hand elsewhere. On the evening of Sunday 8 June, in conformity with the plan for Rebellion, some two dozen croppers had gathered on the outskirts of Huddersfield, with guns and pikes, primed for action. Though they had quickly dispersed, at the approach of the Huddersfield Yeomanry Cavalry, the subsequent revelation of Oliver's activities led to the acquittal of ten men, and the decision to abandon cases against a dozen others. The moral was clear for all to see. At Derby, the courthouse had already been daubed with graffiti exclaiming 'Jurymen - remember Oliver!' ${ }^{64}$

The Special Commission convened at Derby between 16 and 25 October illustrates the government's determination to exact the harshest and most exemplary form of punishment from the Pentrich Rebels, starting with Brandreth. The prosecution secured a press blackout throughout the trials and brought the men up on the severest possible interpretation of High Treason, both as to 'levying war against the King' and maturing 'plans and measures to subvert and destroy the Constitution'. It was the first time that the charge of 'levying war against the King' had been brought against anyone since the Jacobite

\footnotetext{
${ }^{63}$ Stevens, pp. 76-7. A $£ 100$ reward was given to Constable Benjamin Barnes and his four assistants.

${ }^{64}$ A. Brooke and L. Kipling, Liberty or Death. Radicals, Republicans and Luddites, 1793-1823

(Huddersfield: Huddersfield Local History Society, 2012), 69-87.
} 
Rebellion of 1745 - a fact which was not lost on the residents of Derby, which was occupied by Scottish rebels in that year. ${ }^{65}$

The prosecution, which was led by the Attorney General Sir Samuel Shepherd, empanelled a Grand Jury of the well-to-do and brought in 300 specially chosen jurymen, largely comprised of farmers from the heart of the county. Charles Mundy, one of the magistrates who had ridden with the $15^{\text {th }}$ Hussars to Gilt Brook, had previously advised the prosecution to avoid selecting jurymen from areas bordering Nottinghamshire. The government also made sure to delay proceedings until the harvest was over, for fear of aggravating farmers called up for jury-service. ${ }^{66}$

Brandreth's defence, together with that of his fellow rebels, was led by Thomas Denman, the defender of the Nottingham Luddites. Privately, Denman thought his clients were 'as destitute of money as [of] common sense'. Publicly, he argued that, rather than 'levying war against the King', the Rebellion was 'one of those mad and needless riots which were occasionally excited by hunger in all countries and all ages'. The attempt to establish a charge of High Treason was a gross exaggeration. The rebels wanted a bigger loaf, better times and a change of government not to remove the monarch. According to Denman's co-counsel, John Cross, the rebels had been stirred to action by the writings of Cobbett and responded from the depths of despair. But the defence case was hopeless and, after three days, the jury returned a guilty verdict. ${ }^{67}$

Having now lost all chance of saving Brandreth, Denman changed tactics in the trials of Ludlam and Turner. He argued that, such was Brandreth's commanding presence, that the Pentrich Rebels were

${ }^{65}$ For the government's case against the rebels, see TNA, TS 11/131-134; for memories of the '45, see Gurney, I, pp. 190-3.

${ }^{66}$ See R. A. Gaunt, 'Trials and the Retribution. The Fate of the Pentrich Rebels' (forthcoming).

${ }^{67}$ J. Arnould, Memoir of Thomas, First Lord Denman (London: Longmans, Green and Company, 1873), I, pp. 107-11, quote at 115; Gurney, I, pp. 198-200. Also see Nottingham Local Studies Library, Broadside Collection, L34.7, 'Evidence taken on the State Trials at Derby, October 1817' 
seduced by him into perpetrating their Rebellion. In an extended passage, read verbatim in court, he likened Brandreth to Conrad, 'the dark and desperate hero of Lord Byron's tale of The Corsair'. Though this flattering resemblance has contributed significantly to the subsequent mythology surrounding Brandreth, the less flattering context in which it was uttered should probably also be remembered. ${ }^{68}$

Denman's efforts were in vain; Turner and Ludlam took their place alongside Brandreth as convicted traitors, headed for the gallows. George Weightman, who had brought the erroneous news that Nottingham had fallen, did not. Though he was tried and convicted of High Treason, the jury recommended mercy and his sentence was commuted to transportation. ${ }^{69}$

There then followed what can only be regarded as a mutually convenient plea-bargain. Nineteen men, including Thomas Bacon, were the next prisoners scheduled for trial. In exchange for pleading guilty, their sentences were commuted from death to transportation. The arrangement, which appears prudent in light of the guilty convictions already returned on Brandreth, Turner and Ludlam, also had the attraction of sparing any potential embarrassment to the government through raising the matter of Bacon's dealings with Oliver. ${ }^{70}$ Consequently, of the 35 men tried by Special Commission at Derby, 23 were found guilty of High Treason. Twenty of those had their sentences commuted to transportation. The prosecution offered no evidence against the remaining twelve prisoners, who were

\footnotetext{
${ }^{68}$ Bailey, Annals, 297; Arnould, pp. 111-115; Gurney, II, pp. 236-7; Lord Byron, The Corsair, A Tale (London: John Murray, 1814).

${ }^{69}$ NA, DD/E/64/2, 'Sentences of the Prisoners', noted that Weightman's successful plea for clemency was made on 25 October, the anniversary of George III's accession to the throne.

${ }^{70}$ Thomis, 'Guilt of Thomas Bacon', 41-4.
} 
mostly young men. They were released with a stern injunction from the presiding judge, Sir Richard Richards, to mend their ways. ${ }^{71}$

Sidmouth, who had taken to his bed with ill-health in the autumn, is said to have remarked that the outcome of the trials at Derby did more to restore him than any tonic could have done, whilst Justice Abbott observed that the sentences dispelled the myth that low-born men could not be convicted of High Treason. From his exile in the United States, Cobbett came to an alternative conclusion:

I will give countenance to nothing which appears to me to be an attempt against the life, or the lawful authority, of the king. I detest real traitors from the bottom of my heart. But, as we do not call Russell and Sidney traitors; so I am at liberty to judge, whether I am to consider Brandreth and his associates in that light. ${ }^{72}$

The sentence of death for High Treason was to be 'hung, drawn and quartered'. The Prince Regent, in an act of mercy, commuted the necessity for quartering. Shortly after midday, on Friday 7 November 1817, at the prison at Nun's Green in Derby, Brandreth, Ludlam and Turner were paraded around the prison-yard before being brought to the gallows. Brandreth's final words were a blessing upon everyone, including Lord Castlereagh, the unpopular leader of the House of Commons closely associated with the government's 'repressive' policies. More dramatically, William Turner exclaimed that 'This is the work of the government and Oliver' before being prevented from saying any more. The three men were hanged, using the short-drop method, which slowly strangled them to death. After hanging for half an hour, their bodies were taken down, laid upon a block, and decapitated with an axe. Brandreth's head was raised aloft by the executioner, who turned it to the left, right and centre of the watching crowd with the exclamation 'Behold the head of the traitor, Jeremiah Brandreth!' Later that afternoon, the mortal remains of the three men were deposited in an unmarked grave in the

\footnotetext{
${ }^{71}$ See UNMASC, EMC, R. Collinson, 'Some notes about the Pentridge [sic] rebels and their fate in the penal colony of New South Wales, Australia' (typescript, 1997).

${ }^{72}$ Cobbett's Weekly Political Register, 25 April 1818.
} 
churchyard at St Werburgh's on Friar Gate. Today, the names of Brandreth, Bacon and Weightman, are amongst those commemorated in street names at Giltbrook, close to the site where the Rebellion was brought to a close. ${ }^{73}$

\section{Aftermath in Nottingham}

Brandreth's death did not go unnoticed in Nottingham. In addition to the usual broadsides, retailing the grisly details of the final hours of the condemned men, and the 'striking likeness' of Brandreth, which was on sale within a fortnight of his death, much was made of the letter which he wrote to his wife Ann, shortly before proceeding to the gallows. ${ }^{74}$ In addition to publication in the Nottingham Review, the letter formed the basis for a series of verses, which were published by the Nottingham printer Ordoyno:

This correspondence is the last,

That I can have with thee,

Be as contented as you can,

And do not grieve for me.

May God a comfort be to you,

And my dear children bless,

Which now I leave behind on earth,

${ }^{73}$ See The Times, 8 November 1817, and NA, DD/MI/157, 'A Brief Narrative of the Lives and Execution of Jeremiah Brandreth, William Turner and Isaac Ludlam’.

${ }^{74}$ Nottingham, Review, 21 November 1817. Brandreth's letter is published in Stevens, p. 103. 
Forlorn and fatherless. ${ }^{75}$

Equally significant was the fact that 'Oliver the Spy' continued to be the object of keen interest in the town. Despite persistent attempts by the press and Whig party to make him accountable, Oliver lived out his days in the Cape Colony, aided by government patronage. In January 1818, the Nottingham Review published verses which cursed him for his role in the Rebellion:

Though he sulk in the dark, by others protected,

Who give him a pension his wants to supply;

May conscience torment him, by the world be neglected,

And far from old England in misery die.

Almost a decade later, when Oliver died from gangrene of the bowels, the Review took pleasure in regaling the news to its readers; in doing so, it compared his fate with that of the 'Nottingham Captain':

Hark! From the farthest point of Afric's shore,

A groan of death resounds; a loud deep groan

Which echoes far and near, where'er the tongue

Of infamy has told Britannia's shame.

'Tis Oliver has fallen - the accursed spy,

Long damned to fame eternal; and the ghost,

The exulting ghost of BRANDRETH now may smile

${ }^{75}$ W. F. Patton, 'Political Expression through Song and Verse: Nottingham, 1780-1850' (PhD diss., Queen's University of Belfast, 1983), pp. 352-3. For Ordoyno, see W. J. Clarke, Early Nottingham Printers and Printing (Nottingham: Thomas Forman, 1942) and RBN, p. 212. 
To see him sneak. Yea basely sneak away

From this fair planet which his name hath tarnished. ${ }^{76}$

The avidity with which the Review continued to keep the fate of Brandreth, Oliver and the Pentrich men before the people of Nottingham is notable but predictable, given its source. Charles Sutton had been an inveterate opponent of government, both local and national, throughout the life of the paper and had been imprisoned for his sentiments as recently as $1816 .{ }^{77}$

However, in his editorials, even Sutton was apt to call the Rebellion 'The Derbyshire Plot'. Much earlier, Lancelot Rolleston had told Newcastle that the men brought into Nottingham for incarceration at the County Gaol were 'Derbyshire Men but say they were led on by the Nottingham'. This was a sentiment which Thomas Denman, during the trials of the rebels, was at pains to repel. He disclaimed any connection between events in Pentrich, on the evening of 9-10 June 1817, and the simultaneous gathering of men on the Forest witnessed by William Roper. ${ }^{78}$

\section{Conclusion}

This article has argued that Nottingham was more heavily implicated in the events of the Pentrich Rebellion than has sometimes been appreciated. ${ }^{79}$ Without the strong geographical connections between Nottingham and the villages at the heart of the Rebellion, it is unlikely that the Rebellion would have taken its intended route, heading by way of Butterley towards the Forest at Nottingham.

${ }^{76}$ Patton, 'Political Expression', pp. 356-7; Field, p. 322. Also see K. McKenzie, 'Exit pursued by a bear: Oliver the Spy and the imperial context of British political history', History Australia, 13 (2016), 80-94.

${ }^{77}$ NA, M1000, 'Evidence of frame-breaking in Nottinghamshire, collected for the defence of Charles Sutton' (1811-16).

${ }^{78}$ UNMASC, Ne C 4972, Rolleston to Newcastle, 10 June 1817; Gurney, I, p. 239.

${ }^{79}$ A notable recent exception is R. Tanner, Nottingham and the Pentrich Rising of 1817 (Pentrich: Pentrich and South Wingfield Revolution Group, 2018). 
These connections dated back to the Luddite disturbances of 1811-12, but had been nurtured and expanded subsequently through the Hampden Club movement and the delegate system upon which it relied. Without it, Thomas Bacon could hardly have become connected with Nottingham radicals such as William Stevens nor introduced to those who had fallen on hard times, like Jeremiah Brandreth. Without that system, and those connections, there would have been no recourse for Henry Sampson or 'Oliver the Spy' to be employed as infiltrators (let alone agents provocateurs); it was their intelligence which offered government and local magistrates the opportunity to initiate precautionary measures for a threat they knew was coming. ${ }^{80}$

However, beyond the small circle of committed radicals, and their supporters, the wider temper of Nottingham and its surrounding villages was undoubtedly ambivalent about the Rebellion. In part, this was due to the failures of the radicals themselves to mature significantly effective plans, but it was also a reflection of the careful conciliation of public discontent by the Whig Corporation. Through the targeted expression of criticism against the Tory government in London and the institution of suitable relief for the most distressed, the Corporation succeeded in maintaining vigilance over the unsettled public mood without instituting reactionary measures. Nottingham remained a radical town, in the summer of 1817 , but not a revolutionary one. ${ }^{81}$

Fresh from his defence of the Nottingham Luddites and of Brandreth, Denman considered standing as MP for Nottingham in the General Election of 1818. He was a Foxite by upbringing and 'a good deal connected with Romilly and Lord Holland', the latter of whom was Nottingham's Recorder, but he withdrew in favour of Lord Rancliffe until being elected one of the town's MPs in 1820. By then,

\footnotetext{
${ }^{80}$ For the government's attempt to implicate former Luddites, see Field, pp. 313, 317, and Thomis, Politics and Society, pp. 209-12. See above, note 19.

${ }^{81}$ J. Beckett, A Centenary History of Nottingham (Manchester: Manchester University Press, 1997), chapter 13.
} 
Nottingham had entrenched itself as a Whig stronghold, treading the fine line between revolution and reaction through giving a 'firm and moderate' lead. ${ }^{82}$

On the same day that the Pentrich Rebels were executed, the newspapers brought the intelligence that Princess Charlotte, the only child of George, Prince Regent, had died the day before in childbirth. During the period of national mourning which followed, the poet Percy Shelley was moved to reflect upon the contrast between these two events. How was it, he wondered, that the same nation which could mourn the loss of an innocent, yet highly privileged young woman could, simultaneously, send three men to a brutal death and a common grave? Echoing Thomas Paine's famous phrase, Shelley observed, 'we pity the plumage but forget the dying bird'. Meanwhile, in Nottingham, on the day that Princess Charlotte was buried, we are reliably informed that 'there was a complete suspension of business, and a predominant mournfulness, more general and sincere than can be remembered from any similar event' ${ }^{83}$

\section{Acknowledgements}

This article incorporates research undertaken during a three-year Arts Council England funded academic residency as 'Curator of Rebellion' with Nottingham City Museums and Galleries at Nottingham Castle. It was delivered as a paper at events across Nottinghamshire and Derbyshire

82 See R. G. Thorne, 'Thomas Denman', in The History of Parliament, 1790-1820 <http://www.historyofparliamentonline.org/volume/1790-1820/member/denman-thomas-1779-1854> [accessed August 17, 2018]; S. Harratt and S. Farrell, 'Nottingham' in The History of Parliament, $1820-1832$ <http://www.historyofparliamentonline.org/volume/18201832/constituencies/nottingham> [accessed August 17, 2018].

${ }^{83}$ T. Paine, Rights of Man: Being an Answer to Mr. Burke's Attack on the French Revolution (London: J. S. Jordan, 1791), p. 26; P. Shelley, "We Pity the Plumage But Forget the Dying Bird”. An Address to the People on the Death of the Princess Charlotte (London: Thomas Rodd, 1843); Field, p. 322. 
during the Pentrich bicentenary year, including the 'Radicalism and Popular Protest in Britain, 1790$1820^{\prime}$ conference, held at the University of Derby on 9 June 2017. I am grateful to all those who offered questions and comments on these occasions and to those who read this article prior to publication. 